\title{
Empowering digital learning with open textbooks
}

\author{
Hongliang $\mathrm{Ma}^{1} \mathbb{D}$
}

Accepted: 19 November 2020 / Published online: 14 January 2021

(c) Association for Educational Communications and Technology 2021

\begin{abstract}
This paper is in response to the article entitled "Open educational resources and college textbook choices: a review of research on efficacy and perceptions" (Hilton, 2016). In the article, Hilton synthesized the results of 16 studies, and proposed a statement that the decision to employ and adopt open textbooks in higher education has appeared to have financial benefits to students without decrease in their learning outcomes. This finding would strengthen credibility of open textbooks use and encourage faculty to utilize high-quality open textbooks in a post-pandemic world. However, only if teachers are willing to develop and use open textbooks can millions be saved for students and higher performance be achieved by students. Furthermore, from integrative model of behavior prediction, future research needs to probe a variety of issues relating to how teachers could be intentionally and effectively use open textbooks to empower the digital learning in the 21 st century.
\end{abstract}

Keywords Open textbooks · Digital learning $\cdot$ Learning outcomes $\cdot$ Teacher behavior

Because of the coronavirus pandemic, universities now have the chance to spur a paradigm shift in teaching and learning, meanwhile to reduce the cost of post-secondary education by scaling up creation and use of open educational resources (OER), particularly open textbooks. During the past 20 years, textbook costs have almost doubled, even when controlling for a 55\% inflation rate (Ritholz 2018). It was acknowledged in the Affordable College Textbook Act (S.2176) that the high cost of college textbooks became a barrier for many students in achieving a higher education (Durbin 2015). Open textbooks are Open Educational Resources (OER) created to serve the role of traditional textbooks, and in some cases actually are versions of the commercial textbooks provided under an open license. This makes them free to use and also allows instructors to freely adapt, edit and revise the original content to suit their courses. The field of open textbooks has proven to be one of the most amenable to the open approach, and provides solid evidence of cost savings (Weller 2014). For instance, OpenStax textbooks initiative leads to an estimated US \$3 million savings for students (Green 2013).

Hongliang Ma

mahl@snnu.edu.cn

1 School of Education, Shaanxi Normal University, No.199 Chang'an South Rd., Xi'an 710062,

Shaanxi, China 
As well as the financial impact, there may be a pedagogical one. Dr. Hilton (2016) provided a synthesis of 16 published research performed in higher education settings that utilized OER textbooks, and described, summarized and discussed the efficacy of OER and the perceptions of students and teachers of OER These embodies two important strands of COUP Framework offered by the Open Education Group at Brigham Young University: outcomes and perceptions. Results indicated that students generally have achieved same learning outcomes, and both students and faculty have been generally positive regarding OER. Hilton's literature review provides timely and valuable information given the vast amount of money spent on traditional textbooks in recent years, especially facing the financial difficulties in this pandemic world. As Hilton questioned in the conclusion: "If the average college student spends approximately $\$ 1000$ per year on textbooks and yet performs scholastically no better than the student who utilizes free OER, what exactly is being purchased with that $\$ 1000$ ?" In the end he proposed the last statement tentatively that the decision to employ and adopt OER in higher education has appeared to have financial benefits to students without decrease in their learning outcomes. Furthermore, he argued that the rationale for requiring students to purchase commercial textbooks maybe need to be more carefully examined when high-quality, free and openly-licensed textbooks are available. Therefore, his research would strengthen credibility of OER use and encourage faculty to utilize high-quality open textbooks and integrate them into face-to-face instruction and could transform students' learning into digital learning with significant cost savings and no decrease in student academic outcomes.

It is also valuable to note that Hilton proposed in this paper that future studies incorporate stronger research designs to sufficiently claim causality, such as controlling for teacher and student effects, randomization of treatment and control groups or utilization of propensity score matching. This proposal has been reflected in new literatures (Beile et al. 2020; Cuttler 2019; Hilton et al. 2019; Winitzky-Stephens \& Pickavance 2017). For instance, Winitzky-Stephens and Pickavance (2017) used a multilevel modeling approach in order to control for student, instructor and course effects, and found no difference between courses using OER and traditional textbooks for continuing students. Based on controlling for pedagogical differences by exploring patterns involving the same course and same instructor, Beile et al. (2020) compared student academic outcomes both prior to and after adoption of the open textbooks, and found that students who used the open textbooks performed equally well as students using the traditional textbooks. These findings with rigorous research design are aligned with Hilton' statement about the efficacy of OER.

Although the use of open textbooks in universities is changing the higher education landscape and is promising for the mainstream adoption of OER (Algers 2019), further research is still needed to explore ways to increase faculty adoption, use, adaption and production of OER (Bethel 2020; Hilton et al. 2019), develop a practical measure for evaluating open textbook quality (Fischer et al. 2017), and investigate the pedagogical implications of openness on educator and learner practices (Paskevicius \& Irvine 2019; Rolfe 2017).

However, only if teachers are willing to develop and use open textbooks can millions be saved for students and higher performance be achieved by students. According to Integrative Model of Behavior Prediction (Fishbein \& Ajzen 2011), attitude, selfefficacy and perceived norm are assumed to influence behavioral intention, together with knowledge and skills, and facilitating conditions. All these factors will influence teachers' actual behavior. From perspective of the integrative model, it can be inferred that faculty will develop and use open textbooks on their intentions when they have the necessary skills and when university environmental factors do not impede their usage 
performance. Therefore, although the cost story is quite clear, teacher intentions, skills and their environmental constraints of open textbooks usage are still vague. Future research needs to probe a variety of issues relating to how teachers could be intentionally and effectively use open textbooks to empower digital learning in the 21 st century.

\section{Compliance with ethical standards}

Conflict of interest All authors declare that they have no conflict if interest.

\section{References}

Algers, A. (2019). Open textbooks: A balance between empowerment and disruption. Technology, Knowledge and Learning, 25(3), 569-584.

Beile, P., deNoyelles, A., \& Raible, J. (2020). Analysis of an open textbook adoption in an American history course: Impact on student academic outcomes and behaviors. College \& Research Libraries, 81(4), 721-736.

Bethel, E. (2020). Open textbooks: Quality and relevance for postsecondary study in the Bahamas. The International Review of Research in Open and Distance Learning, 21(2), 61-80.

Cuttler, C. (2019). Students' use and perceptions of the relevance and quality of open textbooks compared to traditional textbooks in online and traditional classroom environments. Psychology Learning and Teaching, 18(1), 65-83.

Durbin, R. J. (2015). Affordable college textbook act, Washington, DC: GPO, Section 2. Retrieved 25 July, 2020, from https://www.congress.gov/bill/114th-congress/senate-bill/2176/text.

Fischer, L., Ernst, D., \& Mason, S. (2017). Rating the quality of open textbooks: How reviewer and text characteristics predict ratings. The International Review of Research in Open and Distance Learning, 18(4), 142-154.

Fishbein, M., \& Ajzen, I. (2011). Predicting and changing behavior: The reasoned action approach. New York, NY: Psychology Press. https://doi.org/10.4324/9780203838020.

Green, C. (2013). The impact of open textbooks at OpenStax college. Retrieved 8 July, 2020, from https ://creativecommons.org/weblog/entry/38890.

Hilton, J. (2016). Open educational resources and college textbook choices: A review of research on efficacy and perceptions. Educational Technology Research and Development, 64(4), 573-590.

Hilton, J., Larsen, R., Wiley, D., \& Fischer, L. (2019). Substituting open educational resources for commercial curriculum materials: Effects on student mathematics achievement in elementary schools. Research in Mathematics Education, 21(1), 60-76.

Paskevicius, M., \& Irvine, V. (2019). Open education and learning design: Open pedagogy in praxis. Journal of Interactive Media in Education, 10(1), 1-10.

Ritholz, B. (2018). Price changes (Jan. 1997-Dec. 2017): Selected US Consumer Goods and Services, and Wages. Retrieved 23 July, 2020, from https://ritholtz.com/wp-content/uploads/2018/02/price changes.png.

Rolfe, V. (2017). Striving toward openness: But what do we really mean? The International Review of Research in Open and Distance Learning, 18(7), 75-88.

Weller, M. (2014). The battle for open: How openness won and why it doesn't feel like victory. London: Ubiquity Press.

Winitzky-Stephens, J., \& Pickavance, J. (2017). Open educational resources and student course outcomes: A multilevel analysis. The International Review of Research in Open and Distance Learning, 18(4), 35-49.

Publisher's Note Springer Nature remains neutral with regard to jurisdictional claims in published maps and institutional affiliations. 
Dr. Hongliang Ma is a professor of Educational Technology, the Executive Director of National Research Center for K-12 IT Curriculum and Instruction at Shaanxi Normal University. His research focuses on the design and development of OER for K-12 students and the teacher professional development in computer science. 